\title{
FORAMINIFERA AND PALAEOENVIRONMENT OF ELEVATED LATE PLEISTOCENE SANDS, WHITE ROCK POINT, SOUTHEASTERN TASMANIA
}

\author{
by Dale Lewis and Patrick G. Quilty
}

(with three text-figures, one plate, one table and one appendix)

Lewis, D. \& Quilty, P.G. 2009 (11:xii): Foraminifera and palaeoenvironment of elevated Late Pleistocene sands, White Rock Point,
southeastern Tasmania. Papers and Proceedings of the Royal Society of Tasmania 143(2): 95-100. https://doi.org/10.26749/rstpp.143.2.95

ISSN 0080-4703 School of Earth Sciences, University of Tasmania, Private Bag 79, Hobart, Tasmania 7001, Australia. (DL,

PGQ*). *Author for correspondence. Email: P.Quilty@utas.edu.au

A well-preserved foraminiferal fauna similar to that living in nearby Ralphs Bay in southeastern Tasmania is documented frøm raised shallow-water sediment of 130-119 Ka age (Late Pleistocene; Marine Isotope Stage 5e) at about $24 \mathrm{~m}$ above modern sea level $\bullet$ n White Rock Point. Foraminifera and sediment characteristics indicate that deposition occurred in very shallow, highly oxygenated, high-energy marine conditions in an area of open circulation. There is very little infauna. The locality is the only known site for such a fauna from before human habitation of the Derwent Estuary region, and allows comparison with modern faunas.

Key Words: Pleistocene, Foraminifera, palaeoenvironment, Tasmania.

\section{INTRODUCTION}

Much has been written since the visit of Charles Darwin to Hobart in 1836 (Darwin 1891, Sutherland 1971, Banks 1971, Bowden \& Colhoun 1984, Banks \& Leaman 1999, M. Davies 2009) concerning possible "young" uplift or neotectonic activity of Tasmania. Darwin (1891) discussed briefly evidence in the form of raised shell beds in the vicinity of Hobart, and Banks (1971) and Banks \& Leaman (1999) expanded on that comment, using Darwin's own diaries. Unfortunately, many of the localities Darwin visited are now altered or inaccessible because of development. Darwin referred to the then current belief by the "colonists" that most shell beds were the result of transport by Aborigines but his view was that "... the greater number [is due] to a small elevation of the land" (Darwin 1891 p. 158).

The question of rejuvenation of tectonically-controlled land level and its causes has become of recent interest with the need to differentiate evidence of land elevation change versus sea level change (Dickinson et al. 2002, Sandiford 2003, 2007, Sandiford et al. 2004). Tasmania has several recognised surfaces such as the Milford (c. $1 \mathrm{~m}$ above modern sea level) and Llanherne $(4 \mathrm{~m})$ surfaces of J.L. Davies $(1951,1961)$ who ascribed changes in level to variation in sea level. The Milford level was associated with a sea level highstand at 6-Ka. His papers did not refer to the higher level sediment studied here.

Unconsolidated sediment to $24 \mathrm{~m}$ above sea level (m.a.s.l.) occurs on White Rock Point (42 $58^{\prime}$ S, $147^{\circ} 24.3^{\prime} \mathrm{E}$ ), on the peninsula immediately north of Opossum Bay, southeastern Tasmania (figs 1, 2). This is recorded as Mary Ann Bay sandstone on Leaman (1972). The sediment is not of middens, which do occur nearby, but undisturbed natural sediments, lying where deposited. This site, commonly referred to as Mary Ann Bay, is critical in the discussion of uplift because it appears to be the sole locality in the Tasmanian region which has yielded fossil-based information on elevation and age, thus allowing an estimate of rates of change of uplift. The sediments contain the only known "young" fauna from pre-human activity in the region.
The sediment has been dated by Murray-Wallace et al. (1990) and Murray-Wallace \& Goede $(1991,1995)$ to the Last Interglacial Maximum, Marine Isotope Stage (MIS) 5e or 130-119 000 years, using amino acid racemisation and electron spin resonance techniques. These ages suggest deposition when sea level may have been a few metres above current (Hearty et al. 2007) but the true sea level difference depends on where, in the interval 130-119 Ka, the age of the sediment falls. This is unclear as yet. The subject of precise dating of, and sea level variation during, the Last Interglacial interval is contentious at present (Edwards et al. 1987, Szabo et al. 1994, Slowey et al. 1996, Muhs et al. 2002) and other dating techniques such as U/Th may be useful in placing this material in the context of climate change controlled by orbital forcing (the Milankovitch hypothesis).

The sediment is described in detail by Murray-Wallace et al. (1990). It consists of well-sorted quartz sand from more than one immediate source and contains grains, dominantly medium sand fraction, that vary from very well rounded to fresh, angular, commonly with some crystal faces indicating recent release from local high porosity Triassic sandstone. The sediment is cross-bedded and most molluscs are highly fragmented, suggesting deposition in shallow marine, highenergy conditions typical of small bays currently found around the peninsulas of South Arm and Tasman Peninsula (fig. 1). The sediments contain a diverse fauna of extant molluscs (Colhoun et al. 1982).

In addition to the molluscs, the sediments contain a significant foraminiferal fauna of species that are well-known in the vicinity (Harris 1969, Lewis 2006). They are wellpreserved and thus allow comparison of conditions between pre- and post-human, occupation of the region, including geochemical signals in the calcium carbonate skeletons.

This paper documents the foraminiferal fauna, uses it to place limits on the palaeoenvironment at 130-119 Ka and establishes a foraminiferal baseline for southeastern Tasmanian Foraminifera from an environment that existed prior to disturbance by human activities. 


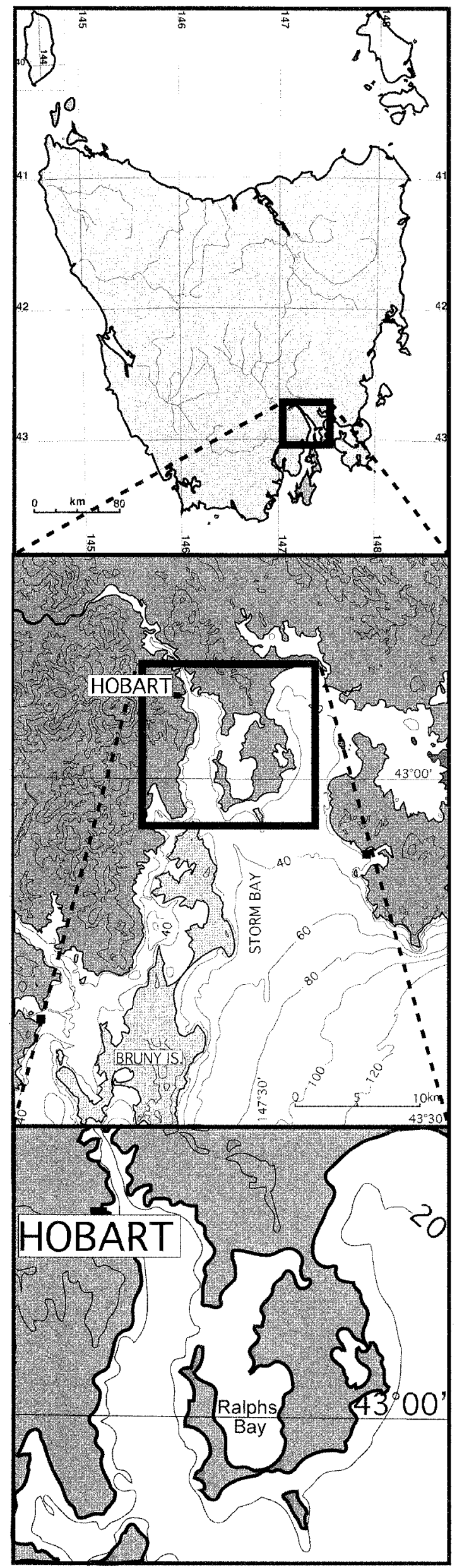

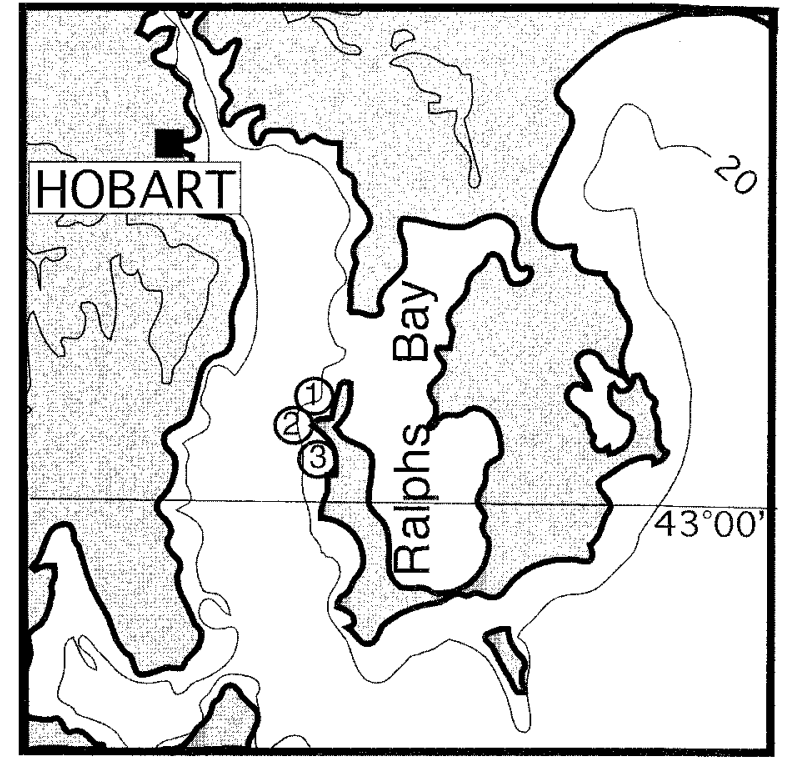

FIG. 2 - Detail of location of three specimens studied.

\section{MATERIAL AND METHODS}

Three samples (A, B and C) were collected from steep faces on the western side of the outcrop. As the sand is unconsolidated, processing consisted of simple washing of $3 \times 20 \mathrm{~g}$ samples over nested sieves at $63,125,250$ and $500 \mu \mathrm{m}$ but only those resting on sieves coarser rhan $125 \mathrm{~mm}$ were examined. Washed residues were reduced in size by a sample splitter to yield statistically sound foraminiferal faunas; thus only $25 \%$ or $12.5 \%$ of the sample was picked to give the specimen count shown in table 1 . Foraminifera were separated by standard methods, placed in cardboard slides and identified. The distribution of the Foraminifera is shown in table 1 and nomenclature followed is provided in appendix 1 .

The material is well-preserved and there is no indication in the Foraminifera of damage through diagenesis although many specimens have minor abrasion or breakages consisrent with a high-energy environment; thus the final chamber wall of Ammonia aoteana (Finlay, 1940) commonly is broken but the rest of the test is well-preserved. While the robust environment is a likely cause, the broken final chamber could also be an arrefact of reproduction. There may also have been minor dissolution of test surfaces due to percolating meteoric waters but there is no evidence for significant dissolution in either molluscs or foraminiferal populations.

Species were identified using the studies by Yassini 8 Jones (1995), Hayward et al. (1999) and Lewis (2006). Once identified, a variety of standard techniques was used to categorise the fauna and to inrerpret the palaeoenvironment.

Samples studied and fossils illustrated are caralogued in the collection of the School of Earth Sciences, University of Tasmania, and the number following the initials UTGD is the accession number in that collection. Illustrated specimens (pl. 1) are in the range 128811-128822 and the hand specimens, washed residues and assemblage slides in 160918.

FIG. 1 - Locality map. 
TABLE 1

Species recorded in subsets of three samples from the western side of the Mary Ann Bay outcrop

\begin{tabular}{|c|c|c|c|}
\hline$\overline{\text { Species }}$ & $\begin{array}{c}\text { Sample } \\
\text { A }\end{array}$ & $\begin{array}{c}\text { Sample } \\
\text { B }\end{array}$ & $\begin{array}{c}\text { Sample } \\
\mathrm{C}\end{array}$ \\
\hline \multicolumn{4}{|l|}{ Benthic species } \\
\hline Ammonia doteana & 87 & 76 & 37 \\
\hline Bulimina gibba & 2 & & \\
\hline Cibicides refulgens & 16 & 8 & 1 \\
\hline Elphidium advenum advenum & 6 & 8 & 5 \\
\hline E. advenum maorium & & 1 & \\
\hline E. crispum crispum & 3 & & 3 \\
\hline E. excavatum clavatum & 5 & 2 & \\
\hline E. hawkesburiense & 27 & 33 & 10 \\
\hline Notorotalia clathrata & 10 & 2 & 4 \\
\hline Parrellina verriculata & & 1 & \\
\hline Trifarina pacifica & 1 & 1 & \\
\hline Uvigerina bassensis & 1 & & \\
\hline \multicolumn{4}{|l|}{ Planktonic species } \\
\hline Globigerina bulloides & & & 1 \\
\hline Total & 157 & 132 & 61 \\
\hline Specimen count $/ 20 \mathrm{gm}$ & 628 & 1056 & 488 \\
\hline Diversity & 6 & 4 & 4 \\
\hline Dominance & 55 & 58 & 61 \\
\hline Fisher a Index & 3 & 3 & 2 \\
\hline
\end{tabular}

\section{FORAMINIFERAL FAUNA}

The fauna is remarkably similar between samples. Diversity is low as expected in the palacoenvironment envisaged. Ammonia aoteana is dominant (55-61\%). The next most abundant species is Elphidium hawkesburiense (Albani, 1974) (16-25\%). Other species make up lesser proportions of the samples. Sample A contains $2 \%$ infaunal species (Uvigerina bassensis Parr, 1950 and Bulimina gibba Fornasini, 1902), and samples $A$ and $B$ yielded a few infaunal Trifarina pacifica (Albani, 1974).

Miliolids and cassidulinid species are absent as are agglutinated forms showing that there is no evidence of reduced salinity or limited circulation.

Hayward et al. (1999) regarded $A$. aoteana as a subspecies of $A$. parkinsoniana (d'Orbigny, 1839) but we take it to be a valid species in its own right.

\section{Dominance/diversity}

Walton (1964) studied the distribution of several hundred samples from the Gulf of Mexico and plotted diversity and dominance. Dominance (the percentage of the fauna made up of the dominant species) for White Rock Point ranges from 55 to 60 , and diversity (the number of species making up $95 \%$ of the fauna) is $4-6$. The corresponding Fisher a Index (Fisher et al. 1943, Williams 1964, Quilty \& Hosie 2006) is 2 to 3 . Figure 3 shows the White Rock Point samples plotted on Walton's 0-10 fathom field, suggesting that species in the samples bear the same relationship to each other in the samples as they did in life. Thetefore, the faunas are neither mixed with those from any other source, and not have any species have removed from the parent sediment.

\section{Faunal assemblage structure}

There is a single occurrence of a planktonic foraminifer (Globigerina bulloides d'Orbigny, 1826). This is normal for sediments deposited close to a sandy beach in a shallow bay with open circulation. The ratio of infaunal/epifaunal species commonly is used as an index of nutrient supply (Corliss \& Chen 1988, Murray 1991). In this case, there are very few infaunal species consistent with other evidence for a shallow-water, high-energy, highly oxygenated environment.

\section{Comparison with nearby modern faunas}

All species recovered are known locally and all areextant. Lewis (2006) has studied these species from the Pitt Water/Frederick Henry Bay area and has documented the environmental preferences of the species identified.

Deposition occurred in very shallow, high-energy, fully marine waters consistent with the evidence from the mollusc fauna discussed by Colhoun et al. (1982).

\section{CONCLUSIONS}

Marine sediments from about 24 m.a.s.l. at White Rock Point, southeastern Tasmania, have yielded a low diversity fotaminiferal fauna typical of those to be found in the region today in shallow water, high-energy environments only a few metres deep. There is no evidence of recycling and the fauna is in situ and suffering only minor abrasion as expected in that environment.

Age determination by amino-acid stratigraphy and electron spin resonance has provided control to show the sediments were deposited during MIS 5e (130-119 Ka). Sea level at the time was above modern but estimates of the amount vaty $(2-4 \mathrm{~m})$ and also depend on where in the interval the age lies. It would be worthwhile trying to limit the dates

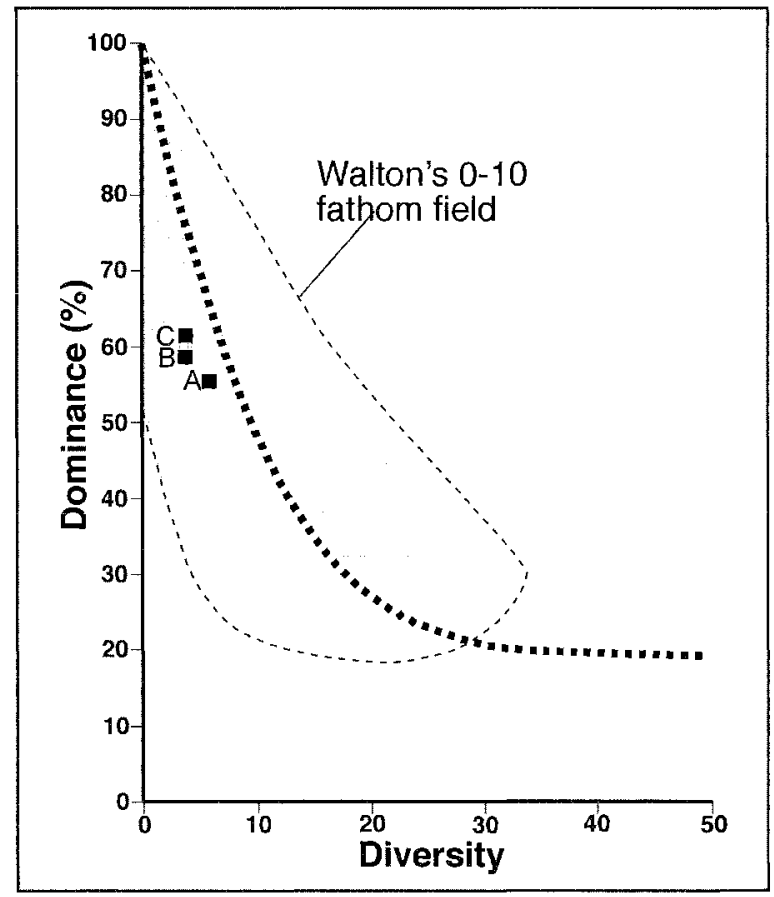

FIG. 3 - Dominance vs diversity and comparison with Walton's (1964) 0-10 fathom field for the Gulf of Mexico. 


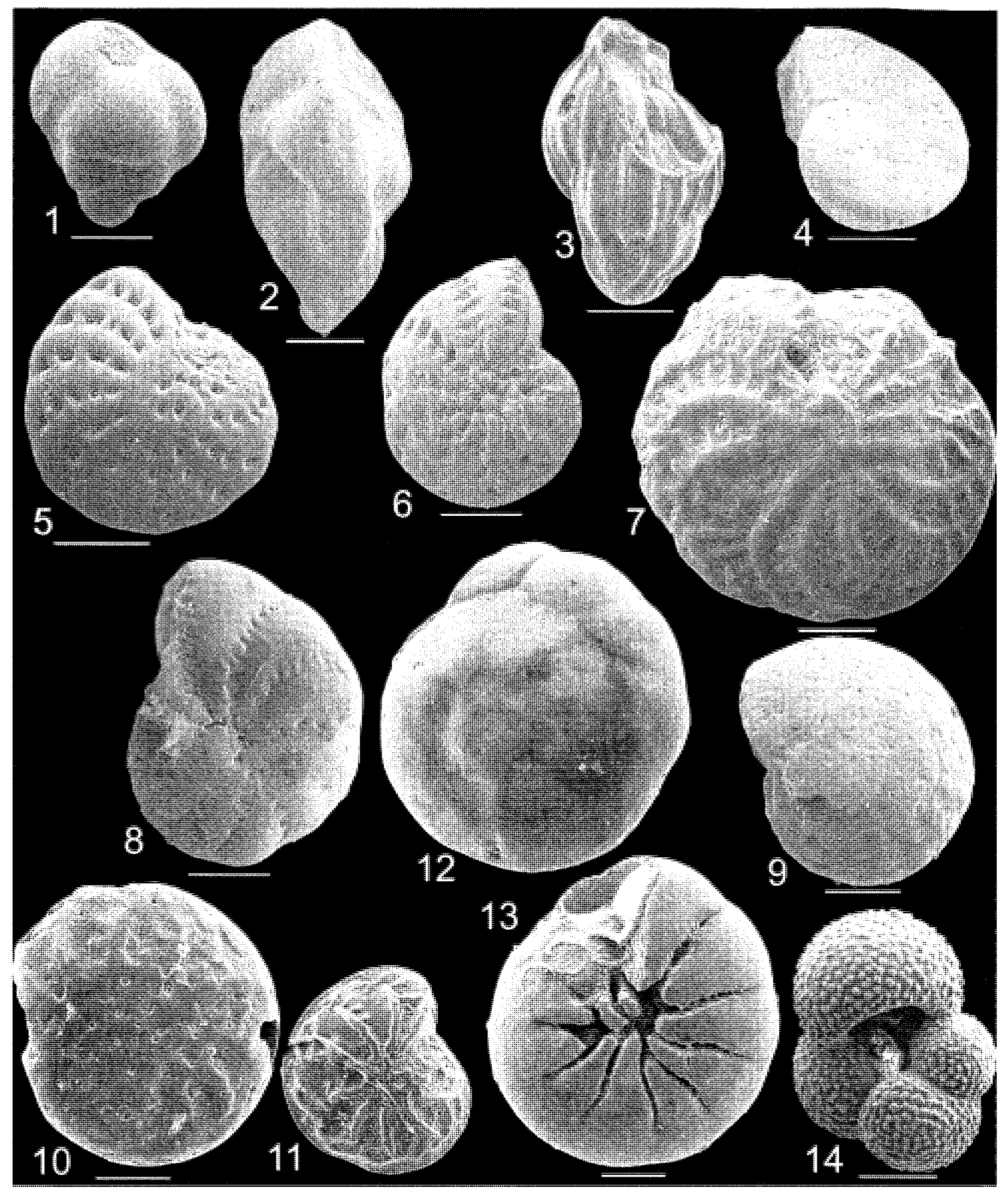

PLATE 1

Species identifled from White Rock Point samples. Scale: 100 microns.

1. Bulimina gibba, profile view, UTGD128811; 2. Trifarina pacifica, longitudinal profle, UTGD128812; 3. Uvigerina bassensis, longitudinal profile, UTGD128813; 4. Cibicides refulgens de Montfort, 1808, oblique ventral surface, UTGD128814; 5. Elphidium advenum advenum), lateral view, UTGD128815; 6. Elphidium excavatum clavatum, lateral view, UTGD128816; 7. Elphidium crispum crispum lateral view, UTGD128817; 8. Elphidium advenum maorium, lateral view, UTGD128818; 9. Elphidium hawkesburiense), lateral view, UTGD128819; 10,11. Notorotalia clathrata dorsal and ventral views UTGD128820; 12, 13.Ammonia aoteana dorsal and ventral views, UTGD128821; 14. Globigerina bulloides, apertural view, UTGD128822. 
further using other techniques such as the U/Th method to allow more refined placement in the context of orbitally controlled climate change models.

The locality has been uplifted since deposition but estimates of the amount and rate of uplift rate depend on more refined age determination and of sea level at the time. The locality is the only site in Tasmania to provide information on faunas from before human habitation of the region. It would be very valuable if more such localities could be identified to further calibrate the uplift history.

\section{ACKNOWLEDGEMENTS}

We thank Prof. Eric Colhoun, University of Newcastle, New South Wales, for drawing our attention to the existence of the sediments and Dr Albert Goede, University of Tasmania, for advice and assistance in obtaining samples. SEM imaging was conducted at the Central Science Laboratory at the University of Tasmania and we say thank you to Dr K. Goemann for assistance. DrW. Howard, ACE CRC, University of Tasmania, helped with discussions on sea level at the time of deposition of the sediments. We thank Drs S. Gallagher and D. Haig for constructive reviews.

\section{REFERENCES}

Albani, A. 1974: New benthic Foraminiferida from Australian waters. Joumal of Foraminiferal Research 4: 9-33.

Banks, M.R. 1971: A Darwin manuscript on Hobart Town. Papers and Proceedings of the Royal Society of Tasmania 105: 5-19.

Banks, M.R. \& Leaman, D. 1999: Charles Darwin's field notes on the geology of Hobart Town - a modern appraisal. Papers and Proceedings of the Royal Society of Tasmania 133: 29-50.

Banner, F.T. \& Blow, W. H. 1960: Some primary types of species belonging to the Superfamily Globigerinacea. Contributions from the Cushman Foundation for Foraminiferal Research 11: $1-41$.

Brady, H.B. 1881: Notes on some of the reticularian Rhizopoda of the Challenger Expedition; part 3. Quarterly Journal of the Microscopical Society, new series 21: 31-71.

Brady, H.B. 1884: Report on the foraminifera dredged by H.M.S. Challenger, during the years 1973-1876: Report on the Scientific Results of the Voyage of H.M.S. Challenger 1873-1876, Zoology 9: $814 \mathrm{pp}$.

Bowden, A.R. \& Colhoun, E.A. 1984: Quaternary emergent shorelines of Tasmania. In Thom, B.G. (ed.): Coastal Geomorphology in Australia. Academic Press, Sydney: 313-342.

Colhoun, E.A., Turner, E.A. \& Van De Geer, G. 1982. Late Pleistocene marine molluscan faunas from four sites in Tasmania. Papers and Proceedings of the Royal Society of Tasmania 116: 91-96.

Corliss, B.H. \& Chen, C. 1988: Morphotype patterns of Norwegian deep-sea benthic foraminifera and ecological implications. Geology 16: 716-719.

Cushman, J.A. 1922: Shallow-water foraminifera of the Tortugas region. Publication of the Carnegie Institution no. 311, Department of Marine Biology Papers 17: 1-85.

Cushman, J.A. 1930: The foraminifera of the Atlantic Ocean, Part 7: Nonionidae, Camerinidae, Peneroplidae and Alveolinellidae. Bulletin of the United States National Museum 104: 1-79.

Darwin, C. 1891: Van Diemens Land. Geological Observations on the Volcanic Islands and Parts of South America visited during the Voyage of H.M.S. 'Beagle'. 2nd edn. Smith Elder \& Co., London: 154-160.

Davies, J.L. 1959: Sea level change and shoreline development in south-eastern Tasmania. Papers and Proceedings of the Royal Society of Tasmania. 93: 89-95.

Davies, J.L. 1961: Tasmanian beach ridge systems in relation to sea level change. Papers and Proceedings of the Royal Society of Tasmania 95: 35-40.

Davies, M. (ed.) 2009: Charles Darwin in Hobart Town. Royal Society of Tasmania, Hobart: 124 pp.

Dickinson, J.A., Wallace, M.W., Holdgate, G.P., Gallagher, S.J. 8 Thomas, L. 2002: Origin and timing of the MiocenePliocene unconformity in southeastern Australia. Journal of Sedimentary Research 72: 317-332.

Edwards, R.L., Chen, J.H., Ku, T.-L. \& Wasserburg, G.J. 1987 . Precise timing of the last interglacial period from mass spectrometric determination of Thorium-230 in corals. Science 236: 1547-1553.

Finlay, H.J. 1940: New Zealand foraminifera: key species in stratigraphy - No. 4. Transactions of the Royal Society of New Zealand 69: 448-472.

Fisher, R.A., Corbet, A.S. \& William, C.B. 1943: The relation between the number of species and the number of individuals in random samples of an animal population. Journal of Animal Ecology 12: 42-58.

Fornasini, C. 1902: Contributo a la conoscenza de la Bulimine Adriatiche. Memorie della Reale Accademie della Scienze dell' Istituto di Bologna, Scienze Naturali, ser. 5, 9: 371-381.

Harris, M.F 1969: Sedimentology of Pittwater, Tasmania. Unpublished Honours thesis, University of Tasmania.

Hayward, B.W., Grenfell, H.R., Reid, C.M. \& Hayward, K.A. 1999: Recent New Zealand shallow-water benthic foraminifera: taxonomy, ecologic distribution, biogeography, and use in paleoenvironmental assessment. Monograph of the Institute of Geological and Nuclear Sciences 21: 258 pp.

Hayward, B.W., Hollis, C.J. \& Grenfell, H.R. 1997: Recent Elphidiidae (Foraminiferida) of the south-west Pacific and fossil Elphididae of New Zealand. Monograph of the Institute of Geological and Nuclear Sciences 16: 1-166.

Hayward, B.W., Holzmann, M., Grenfell, H.R., Pawlowski, J. \& Triggs, C.M. 2004: Morphological distinction of molecular types in Ammonia - towards a taxonomic revision of the world's most commonly misidentified foraminifera. Marine Micropaleontology 50: 237-271.

Hearty, P.J., Hollin, J.T., Neumann, A.C., O'Leary, M.J. \& McCulloch, M.T. 2007: Global sea-level fluctuations during the Last Interglaciation (MIS 5e). Quaternary Science Reviews 26: 2090-2112. doi:10.1016/j. quascirev.2007.06.019.

Leaman, D.E. 1972. Geological Adlas 1:50 000 series 83125 Zone 7, Sheet 82. Hobart. Geological Survey of Tasmania, Hobart.

Lewis, D. 2006: Modern and recent seafloor environments (sedimentary, foaminiferal and ostracode) of the Pitt Water estuary, south-east Tasmania. 2 vols. 298, 245 pp. Unpublished $\mathrm{PhD}$ thesis, University of Tasmania.

Linné, C. 1758: Systema Naturae per regna tria naturae, secundun classes, ordines, generd, species, cum characteribus, differentiis, synonymis, locis: 10th edn, G. Engelman, Lipsiae, 1: 824 pp.

Montfort, P.D. de 1808: Conchyliologie Systématique et Classification méthodique des coquilles: F. Schoell, Paris, v. 1: 409 pp.

Muhs, D.R., Simmons, K.R., Kennedy, G.L. \& Rockwell, T.K. 2002: The last interglacial period on the Pacific coast of North America: timing and paleoclimate. Bulletin of the Geological Society of America 114: 569-592.

Murray, J.W. 1991: Ecology and Palacoecology of Benthic Foraminifera. Longman Scientific and Technical, England $397 \mathrm{pp}$. 
Murray-Wallace, C.V. \& Goede, A. 1991: Aminostratigraphy and electron spin resonance studies of the late Quaternary sea level change and coastal neotectonics in Tasmania. Zeitschift für Geomorphologie 35: 129-149.

Murray-Wallace, C.V. \& Goede, A. 1995: Aminostratigraphy and electron spin resonance dating of Quaternary coastal neotectonism in Tasmania and the Bass Strait islands. Australian Joumal of Earth Sciences 42: 51-67.

Murray-Wallace, C.V., Goede, A. \& Picker, K. 1990: Last interglacial coastal sediments at Mary Ann Bay, Tasmania, and their neotectonic significance. Quaternary Australasia 8: $26-32$.

Orbigny, A. d'. 1826: Tableau méthodique de la classe des Céphalopodes. Annales des Sciences Naturelles, Paris, ser. 1, 7: 245-314.

Parr, W.J. 1950: Foraminifera. Reports of the British, Australian and New Zealand Antarctic Research Expedition 1929 1931, series B (Zoology and Botany) 5: 233-392.

Quilty, P.G. \& Hosie, G. 2006: Modern foraminifera, Swan River estuary, Western Australia: distribution and controlling factors. Journal of Foraminiferal Research 36: 291-314.

Sandiford, M. 2003: Neotectonics of southeastern Australia: linking the Quaternary faulting record with seismicity and in situ stress. In Hillis, R.R. \& Muller, D. (eds) Evolution and dynamics of the Australian plate. Special Publication of the Geological Society of Australia 22: 101-113.
Sandiford, M. 2007: The tilting continent: a new constraint on the dynamic topographic field from Australia. Earth and Planetary Science Letters 261, 152-163, doi:10.1016/j. epsl.2007.06.023.

Sandiford, M., Wallace, M. \& Coblentz, D. 2004. Origin of the in situ stress field in southeastern Australia. Basin Research 16: 325-338.

Slowey, N.C., Henderson, G.M. \& Curry, W.B. 1996: Direct $\mathrm{U}$-Th dating of marine sediments from the two most recent interglacial periods. Nature 383: 242-244.

Sutherland, F.L. 1971: The question of late Cainozoic uplifts in Tasmania. Search 2: 430-431.

Szabo, B.J., Ludwig, K.R., Muhs, D.R. \& Simmons, K.R. 1994: Thorium-230 ages of corals and duration of the Last Interglacial sea-level high stand on Oahu, Hawaii. Science 266: 93-96.

Walton, W.R. 1964: Recent foraminiferal ecology and paleoecology. In Imbrie, J. \& Newell, N.D. (eds) Approaches to Paleoecology. John Wiley, New York: 151-237.

Williams, C.B. 1964: Patterns in the Balance of Nature. Academic Press, London: $324 \mathrm{pp}$.

Yassini, I. \& Jones, B.G. 1995: Recent Foraminifera and Ostracoda from Estuarine and Shelf Environments on the Southeastern Coast of Australia. University of Wollongong Press, Wollongong: $484 \mathrm{pp}$.

(accepted 6 October 2009)

\section{APPENDIX 1 \\ Nomenclature followed in specific identifications}

The following is not a comprehensive synonymy but provides a reference to a more comprehensive discussion of species.

Ammonia aoteana (Finlay, 1940)

Streblus aoteana Finlay, 1940, p. 461.

Ammonia parkinsoniana f. aoteanai: Hayward et al. 2004, p. 162, pl. 16, figs 709 .

Bulimina gibba Fornasini, 1902, p. 378, figs 32, 34.

Cibicides refulgens de Montfort, 1808, p. 123, p. 122, text-fig. 123.

Elphidium advenum advenum (Cushman, 1922)

Polystomella advena Cushman,1922, p. 56, pl. 9, figs 11, 12.

Elphidium advenum advenum: Hayward et al. 1997, p. 65, pl. 2, figs. 9-18.

Elphidium advenum maorium Hayward et al., 1997, p. 69, pl. 1, fig. 7; pl. 4, figs 11-16; pl. 5, figs 1-5.

Elphidium crispum crispum (Linné, 1758)

Nautilus crispus Linné 1758, p. 709

Elphidium crispum crispum: Hayward et al. 1997, p. 74 pl. 7, figs 13-16; pl. 8, figs 1-9.

Elphidium excavatum clavatum Cushman, 1930

Elphidium incertum (Williamson) var. clavatum Cushman, 1930, p. 20, pl. 7, figs 10a, b.

Elphidium excavatum clavatum Cushman, 1930: Hayward et al. 1997, p. 76, pl. 8, figs 141-7; pl. 9, figs 1-8.
Elphidium hawkesburiense (Albani, 1974)

Cribrononion hawkesburiense Albani, 1974, p. 38, pl. 1, figs 12-14.

Elphidium hawesburiense: Hayward et al. 1997, p. 82, pl. 12, figs 1-4.

Notorotalia clathrata (Brady, 1881)

Rotalia clathrata Brady 1884, p. 709, pl. 107, figs 8, 9.

Notorotalia clathrata:Yassini \& Jones 1995, p. 180, figs 159-161.

Parrellina verriculata (Brady, 1881)

Polystomella verriculata Brady, 1881, p. 66.

Polystomella verriculata: Brady 1884, p. 738, pl. 110, fig. 12.

Parrellina verriculata: Hayward et al. 1997, p. 97, pl. 19, figs $1-3$.

\section{Trifarina pacifica (Albani, 1974)}

Trimosina pacifica Albani, 1974, p. 38, pl. 1, figs. 8,9.

Trimosina pacifica : Yassini \& Jones, 1995, p. 154, fig. 62.

Trifarina pacific: Hayward et al. 1999, p. 134, pl. 9, figs. $25,26$.

Uvigerina bassensis Parr, 1950, p. 340, pl. 12, figs 19, 20.

Globigerina bulloides d'Orbigny, 1826 p. 277 , list no. 1. Globigerina bulloides d'Orbigny 1826: Banner \& Blow, 1960 , p. 3, pl. 1, figs. 1, 4 . 